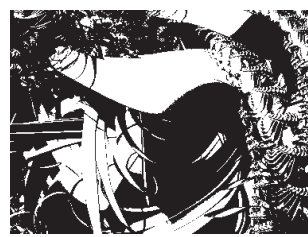

\title{
ASPIRATIONS AND WELL-BEING: EXTRINSIC VS. INTRINSIC LIFE GOALS
}

Majda RIJAVEC

Faculty of Teacher Education, Zagreb

Ingrid BRDAR

Faculty of Arts and Science, Rijeka

Dubravka MILJKOVIĆ

Faculty of Teacher Education, Zagreb

UDK: 159.947 .5

Izvorni znanstveni rad

Primlieno: 20. 7. 2008.

The present study explored whether participants can be classified into groups according to their intrinsic and extrinsic life goals and how these groups differ in satisfaction of basic psychological needs and well-being. Four questionnaires were administered to 835 college students: Aspiration Index (Kasser and Ryan, 1996), The Basic Psychological Needs Scale (Gagnè, 2003), Subjective Vitality Scale (Ryan and Frederick, 1997) and The Satisfaction with Life Scale (Diener at al., 1985). K-Means cluster analysis was used to classify individuals on the basis of their life aspirations: importance, present attainment and likelihood of future attainment. The same four-cluster solution was obtained for all three measures. The first cluster included individuals high on extrinsic and low on intrinsic life goals. The second contained students high on intrinsic and low on extrinsic aspirations. The third group included students with high scores on both intrinsic and extrinsic goals, and the fourth those with low scores on both kinds of goals. The group with high scores on both intrinsic and extrinsic goals had the highest scores on measures of well-being, followed by the group with high intrinsic and low extrinsic aspirations. These two groups had also higher values for all basic psychological needs compared to groups with low scores on intrinsic values. These findings suggest that both intrinsic and extrinsic goals can contribute to well-being.

Keywords: life goals, intrinsic goals, extrinsic goals, psychological needs, well-being 


\section{ASPIRATIONS AND WELL-BEING: EXTRINSIC VS. INTRINSIC LIFE GOALS}

Existential, psychosocial, and organismic theories propose that human beings tend towards greater autonomy (the feeling that they endorse and regulate their own behavior) over the lifespan, and that greater autonomy is associated with greater happiness. Another comprehensive theory focusing on peoples' movement towards greater autonomy over the lifespan is self-determination theory (SDT; Deci and Ryan, 1985, 1991, 2000). This organismic theory of human motivation posits that people have an inherent need for autonomy, that is, the feeling that they endorse and regulate their own behavior. Individuals are more happy and satisfied in life to the extent that they feel more autonomous in their behavior. Much research in the SDT tradition has supported these ideas. Specifically, people acting because of autonomous reasons consistently report greater subjective well-being than those acting because of controlled or externally regulated reasons (see Sheldon, 2002, or Deci and Ryan, 2000, for a review).

Besides autonomy, Deci and Ryan also pointed out the importance of two other psychological needs, competence and relatedness (Deci and Ryan, 1991; Ryan, 1995; Ryan and Deci, 2002). Competence refers to the feeling that one is effective and able in one's behavior, rather than ineffective and inapt (White, 1959) and relatedness refers to the feeling that one is connected to or in harmony with important others, rather than alienated or marginalized (Baumeister and Leary, 1995). According to Deci and Ryan (Deci and Ryan, 1991; Ryan, 1995; Ryan and Deci, 2002), personal well-being is a direct function of the satisfaction of these basic psychological needs. Factors in the person or situation that facilitate autonomy, competence, and relatedness are expected to enhance well-being, whereas factors that detract from fulfillment of these needs should undermine well-being. Sheldon and Elliot (1999) proposed that the accumulation of these three types of experiences over time leads to an increase in longitudinal well-being.

Widely researched goal content distinctions concern the differentiation between intrinsic and extrinsic aspirations (Kasser and Ryan, 1996). Intrinsic goals are defined as those pursuits that are generally congruent with innate psychological needs for relatedness, autonomy, and competence proposed by self-determination theory (Deci and Ryan, 2000; Kasser, 2002b; Ryan and Deci, 2000) and thus are inherently satisfying to pursue, in and of themselves. Intrinsic goals include those for self-acceptance, affiliation, community feeling, and physical health. People striving for these goals are assumed to 
DRUŠ. ISTRAŽ. ZAGREB GOD. 20 (2011), BR. $3(113)$

STR. $693-710$

RIJAVEC, M., BRDAR, I., MILJKOVIĆ, D.: ASPIRATIONS AND... be "in touch" with their deeper nature, and to have a greater chance of finding happiness and well-being (Ryan et al., 1996). In contrast, extrinsic goals are primarily concerned with obtaining some reward or social praise; because they are typically a means to some other end or compensate for problems in need satisfaction, they are less likely to be inherently satisfying (Deci and Ryan, 2000). For instance, research shows that people with strong extrinsic aspirations have more difficulty fulfilling their needs for competence, relatedness, and autonomy (Kasser, 2002a; Kasser et al., 2004; Niemec et al., 2009). Financial success, image, and popularity are common extrinsic goals.

Research has shown that these two types of goals relate in different ways to personal well-being, social behavior, and ecologically-relevant activities (Kasser, 2002a; Saunders, 2001; Saunders and Munro, 2000), and that the two goals are distinguishable using factor analyses in various nations. For example, the structure of goal contents in a group of 1.854 undergraduates from 15 cultures around the world (Grouzet et al., 2005) suggested that the 11 types of goals that were assessed were consistently organized across the 15 cultures - in a circumplex fashion. The circumplex was well described by positing two primary dimensions underlying the goals: Intrinsic (e.g., self acceptance, affiliation) vs. Extrinsic (e.g., financial success, image), and Self-transcendent (e.g., spirituality) vs. Physical (e.g., hedonism). Results obtained from five German samples (Schmuck, 2001) indicate that intrinsic goals are generally valued more highly then extrinsic ones, with subjects strongly focused on intrinsic goals reporting higher well-being than those with a focus on extrinsic goals.

Results from two samples of American college students (Kasser and Ryan, 2001) show that well-being outcomes are differentially associated with a focus on extrinsic aspirations (financial success, social recognition, and appearance) versus intrinsic aspirations (self-acceptance, affiliation, and community feeling). Across ratings of the importance, likelihood of attainment, and current attainment of goals, these findings suggest that a focus on intrinsic goals is associated with greater well-being. On the other hand, a relative focus on extrinsic goals is either negatively or neutrally related to well-being and is associated with lower self-esteem, more television consumption, greater drug use and a lower quality of relationships with friends and romantic partners.

These findings show the cross-cultural generalizability of relationship between life aspirations and well-being. What is more, Sheldon and Kasser (1998) have reported longitudinal data showing that making progress at one's goals only benefits well-being when the goals are intrinsic, not when they are 
DRUŠ. ISTRAŽ. ZAGREB GOD. 20 (2011), BR. $3(113)$

STR. $693-710$

RIJAVEC, M., BRDAR, I. MILJKOVIĆ, D.: ASPIRATIONS AND... extrinsic. The very fact of making progress and attaining goals may be inherently satisfying (Omodei and Wearing, 1990), as it provides individuals with feelings of competence and efficacy (Bandura, 1989).

Intrinsic goals are said to lead to greater satisfaction because they give everyday activities a long-term perspective and encourage other activities in free-time that are self-determined and enjoyable (Deci and Ryan, 1993; Baumeister, 1991). People who have internalized and placed their strongest values upon intrinsic goals are highly likely to engage in behaviors which yield well-being (Kasser and Ryan, 1993, 1996). In contrast, investment in extrinsic goals, even when achieved, may not contribute to well-being. This is presumably because such goals fail to directly satisfy basic needs and because they may distract one from investing in more congruent, intrinsically-oriented goals (Kasser and Ryan, 2001). It seems that extrinsic satisfaction tends to yield more superficial and fleeting positive effects (Richins, 1994; Schwartz, 1994). In fact, extrinsic pursuits may entail ongoing engagement in more pressured, controlling, and competitive settings that are frequently rather stressful (Kasser and Ryan, 1996). Singaporean business students who believed that money, possessions, image and popularity are of large importance reported lessened self-actualization, vitality and happiness, and more anxiety, physical symptoms and unhappiness (Kasser and Ahuvia, 2002).

For the most part, researches have used mainly a correlational method to examine relations between single intrinsic or extrinsic goals and various measures of well-being. There were few attempts to examine how these different goals combine to influence persons' well-being (Kasser and Ryan, 2001). In all these studies, it was assumed that individuals have either well developed intrinsic or extrinsic goals. But it may be possible that some individuals have both types of goals or neither of them.

The main aim of the present study was to explore a possible pattern of classification of participants into groups according to their intrinsic and extrinsic goals. It is possible that they can be classified into two groups with dominantly intrinsic or extrinsic goals. But, as one previous study showed (Peterson et al., 2005), it is also possible that some participants can have high or low both intrinsic and extrinsic goals. Within this aim, possible gender difference will also be examined. We hypothesized that clusters with high intrinsic goals would contain more female participants. That would be in line with some previous research (Kasser and Ryan, 1996; Rijavec et al., 2006).

In addition, it will be examined how obtained groups would differ in satisfaction of basic psychological needs and well-be- 
ing. In line with Self-Determination Theory, we expected that groups with high intrinsic aspirations would have higher values on basic psychology needs and well-being measures compared to groups with low scores on intrinsic aspirations.

METHOD

\section{Participants}

\section{Procedure}

\section{Instruments}

The participants were 835 college students (aged from 19 to 21 years, 534 female and 301 male). 377 students were from Zagreb Faculty of Teacher Education and School for Economy of Entrepreneurship) and 458 from Rijeka (Faculties of Engineering, Law, Medicine, and Economics).

A trained research assistant administered questionnaires to students in groups during regular classes.

Aspiration Index (Kasser and Ryan, 1996)

The 35-item Aspiration Index was used to assess participants' aspirations. The seven categories of aspirations include: the extrinsic aspirations of wealth, fame, and image; the intrinsic aspirations of meaningful relationships, personal growth, and community contributions; and the aspiration of good health which turned out not to be clearly either extrinsic or intrinsic. Participants rate (1) the importance of each aspiration to themselves, (2) their beliefs about the likelihood of attaining each aspiration, and (3) the degree to which they have already attained each of them. The health subscale was excluded from the intrinsic category because it is not a psychologically oriented variable. Principal factor analysis with oblimin rotation confirmed the six-factor solution for all ratings: importance, likelihood of future attainment and present attainment of goals.

A higher order factor analysis verified that the six aspirations do fall into two groups, extrinsic (financial success, fame, and appealing image) and intrinsic (personal growth, affiliation, and community contribution). Past research has shown via higher order factor analysis that intrinsic and extrinsic goals are distinct for both importance and likelihood ratings (Kasser and Ryan, 1996; Schmuck et al., 2000). The correlations between intrinsic and extrinsic factors were: $0.18(p<0.01)$ for importance, $0.42(\mathrm{p}<0.01)$ for attainment of aspirations in future, and $0.47(\mathrm{p}<0.01)$ for present attainment.

Cronbach alphas ranged from 0.70 (present attainment of meaningful relationships) to 0.89 (importance of fame) for 
DRUŠ. ISTRAŽ. ZAGREB GOD. 20 (2011),

BR. 3 (1 13)

STR. 693-710

RIJAVEC, M., BRDAR, I. MILJKOVIĆ, D.:

ASPIRATIONS AND.. six aspiration scales. For two higher order factors Cronbach alphas ranged from 0.84 (present attainment of intrinsic aspirations) to 0.91 (importance of extrinsic aspirations).

\section{The Basic Psychological Needs Scale}

This scale was adapted from a measure of need satisfaction at work (Gagné, 2003). The original scale has 21 items concerning the three needs: for competence, autonomy, and relatedness. On a 7-point scale participants indicate the extent to which the psychological needs of autonomy, relatedness, and competence are generally satisfied in their life. Examples of items are: "I feel like I am free to decide for myself how to live my life" (autonomy), "I really like the people I interact with" (relatedness), and "I often do not feel very capable" (competence).

Principal factor analysis with oblimin rotation confirmed three factors. One item was moved from autonomy and one from competence because of their low correlations with the scale. Cronbach alphas were 0.70 for autonomy scale ( 6 items), 0.73 for relatedness scale ( 8 items), and 0.60 for competence scale (5 items).

The Satisfaction with Life Scale (Diener et al., 1985)

The scale measures life satisfaction as a cognitive-judgmental process. It consists of five statements with a five-point rating scale ranging from "strongly disagree" to "strongly agree". Coefficient Cronbach alpha was 0.72 .

Subjective Vitality Scale (Ryan and Frederick, 1997)

Seven items measure feelings of aliveness and energy on 7-point scales. It can be completed in either state or trait formats, though only the trait format was used for this research. Coefficient Cronbach alpha was 0.79 .

\section{RESULTS}

\section{Cluster Formation}

K-Means cluster analysis was used to classify individuals on the basis of their intrinsic and extrinsic aspirations, separately for goal importance, present and future goal attainment. The assumption was that subjects would be classified into four groups based on the dominating goals; therefore the solution was forced to include four groups.

The cluster analyses confirmed four goal patterns that are consistent with previous research (Kasser and Ryan, 2001). Subjects were classified to following groups, independently for goal importance, present and future goal attainment (Table 1). 
○ TABLE 1

Four clusters in relation to intrinsic and extrinsic goals (z-values)

\begin{tabular}{llrrrr}
\hline & & & & \multicolumn{2}{c}{ Clusters } \\
\cline { 3 - 6 } Classification criterion & Goals & low I/ & $\begin{array}{r}\text { high I/ } \\
\text { low E }\end{array}$ & $\begin{array}{r}\text { low I/ } \\
\text { low }\end{array}$ & $\begin{array}{r}\text { high I/ } \\
\text { high E }\end{array}$ \\
\hline Importance & I & -1.79 & 0.49 & -0.81 & 0.55 \\
& E & -0.89 & -0.75 & 0.21 & 1.06 \\
Present attainment & N & 85 & 271 & 130 & 233 \\
& I & -1.24 & 0.34 & -0.31 & 1.11 \\
Future attainment & E & -0.97 & -0.54 & 0.71 & 1.02 \\
& $\mathrm{~N}$ & 169 & 213 & 137 & 157 \\
& $\mathrm{I}$ & -1.36 & 0.50 & -0.35 & 0.99 \\
& $\mathrm{E}$ & -1.00 & -0.64 & 0.41 & 1.17 \\
& $\mathrm{~N}$ & 144 & 212 & 180 & 159 \\
\hline
\end{tabular}

E - extrinsic goals, I - intrinsic goals

\section{Gender Differences in Cluster Composition}

A chi-square analysis indicated gender differences in cluster membership (Figures 1 and 2).

FIGURE 1

Female distribution across goal clusters in relation to importance, present and future goal attainment

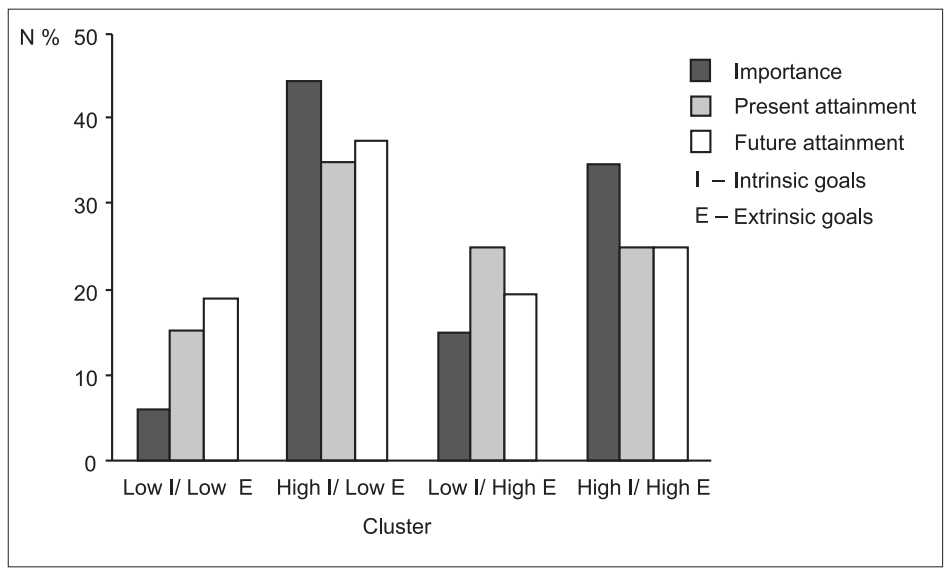

$\rightarrow$ FIGURE 2

Male distribution

across goal clusters in relation to importance, present and future goal attainment

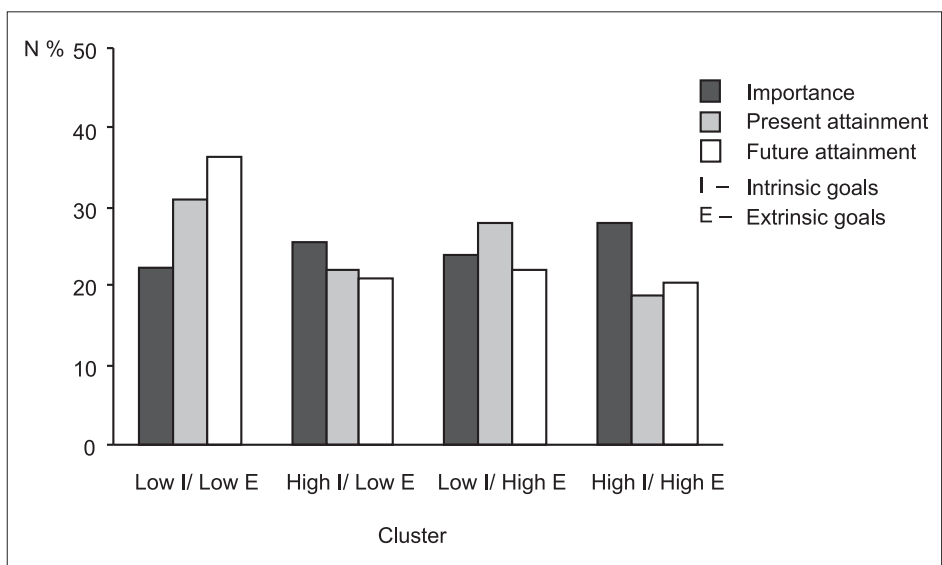


DRUŠ. ISTRAŽ. ZAGREB GOD. 20 (2011)

BR. 3 (113)

STR. $693-710$

RIJAVEC, M., BRDAR, I. MILJKOVIĆ, D.: ASPIRATIONS AND...
Figure 1 shows that both clusters with high intrinsic goals contained more female students for goal importance $\left(\chi^{2}=62.77\right.$, $p<0.01)$, for present goal attainment $\left(\chi^{2}=31.60, p<0.01\right)$, and for future goal attainment $\left(\chi^{2}=34.22, \mathrm{p}<0.01\right)$.

Male students were distributed roughly equally across four clusters (Figure 2). The greatest difference in cluster membership appeared in the first cluster containing individuals with low scores on both intrinsic and extrinsic goals. Compared to other clusters, it contained the smallest number of female students, and the greatest number of male students.

\section{Psychological Needs across Groups}

Psychological needs across groups were examined by one-way ANOVAs. Students who strive for intrinsic goals showed greater satisfaction of basic psychological needs for all three situations - for goal importance, for present and future goal attainment (Figure 3). The cluster containing individuals with high scores on both intrinsic and extrinsic goals generally had

(1) FIGURE 3

Satisfaction of basic psychological needs across clusters for goal importance, future and present goal attainment the highest ratings for needs satisfaction. The cluster containing individuals with low scores on both intrinsic and extrinsic goals had the lowest needs satisfaction ratings. The participants in clusters differed significantly in their ratings of all psychological needs (Appendix 1).

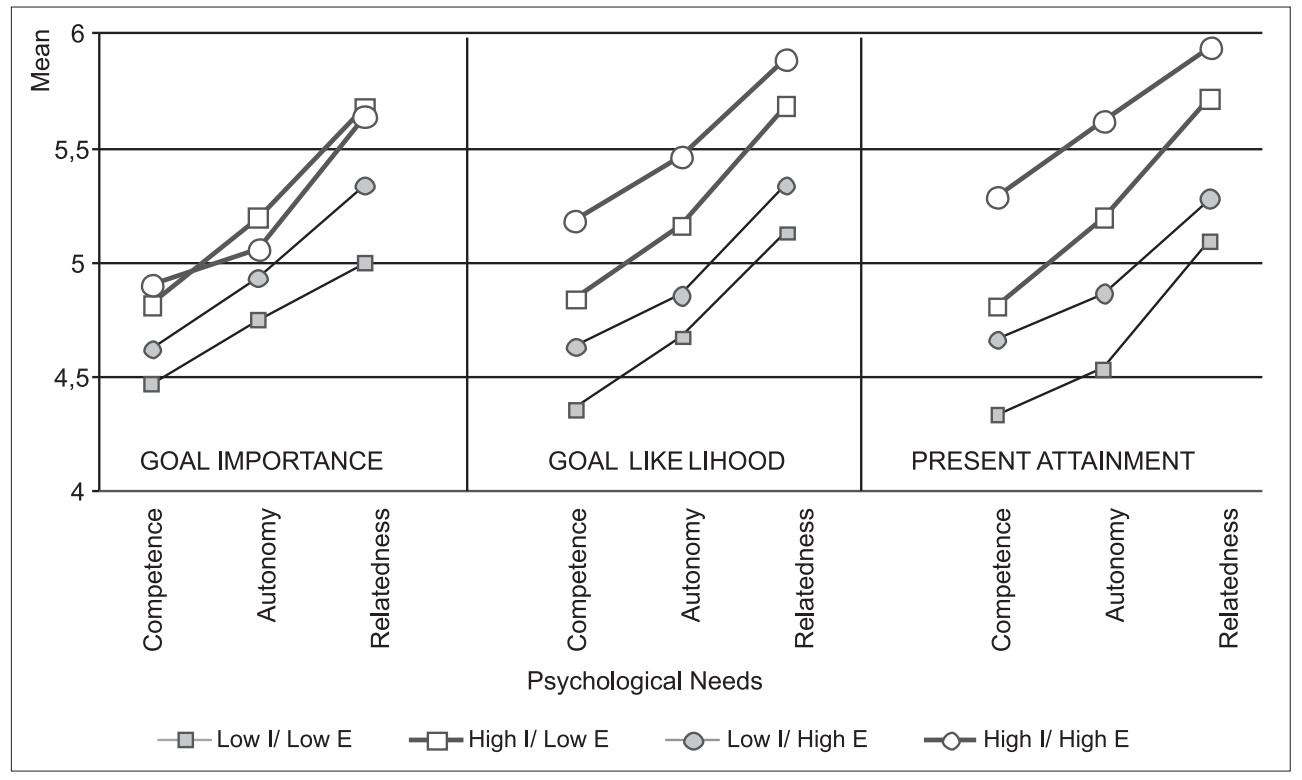

\section{Well-Being across Groups}

One-way analyses of variance showed that the participants in clusters differed significantly in their subjective well-being satisfaction with life and vitality (Appendix 1). Students who strive for intrinsic goals have the highest well-being for all three 
(1) FIGURE 4

Well-being across clusters for goal importance, future and present goal attainment situations (Figure 4). Individuals in cluster with low both intrinsic and extrinsic goals have the lowest satisfaction with life and vitality. This is true for all three situations - for goal importance, for present and future goal attainment.

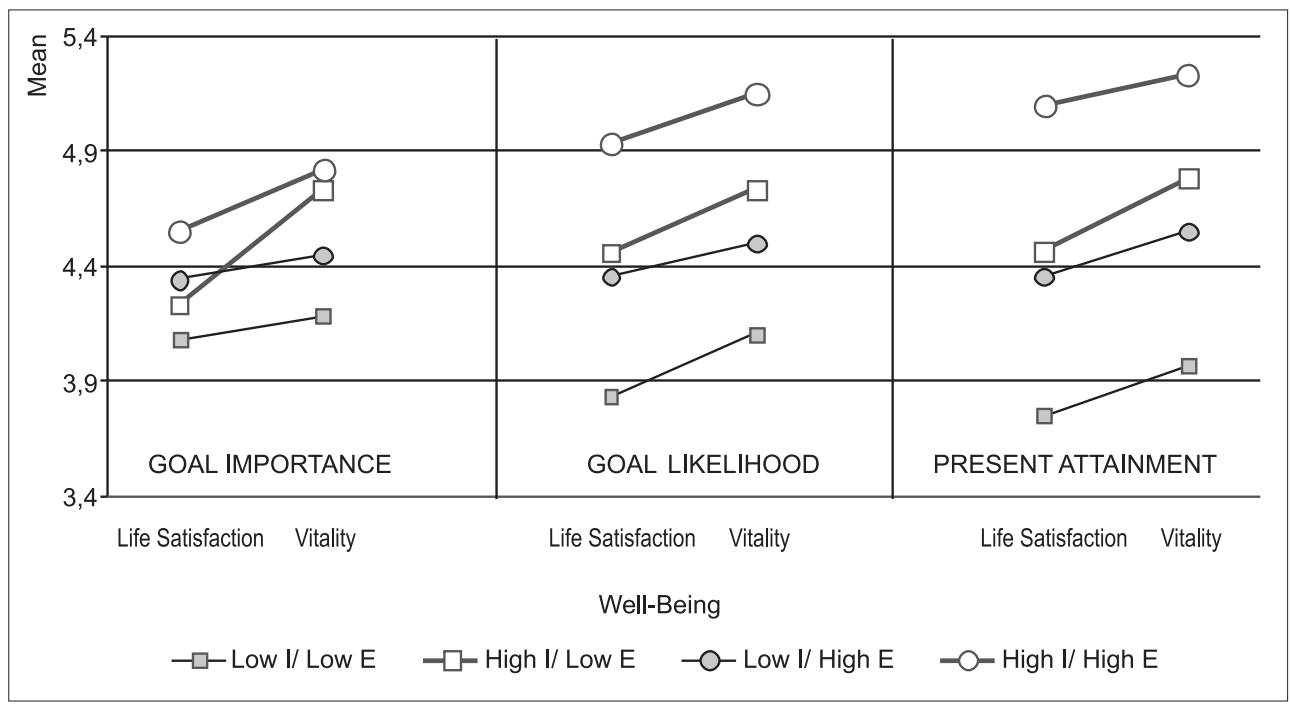

\section{DISCUSSION}

The cluster analyses confirmed four goal patterns that are consistent with previous research (Kasser and Ryan, 2001). The first cluster contained individuals low on both types of goals, intrinsic and extrinsic. These students apparently had no clearly defined life goals. The second cluster included individuals high on intrinsic and low on extrinsic aspirations. The third cluster contained individuals low on intrinsic and high on extrinsic goals and the fourth those high on both types of goals. The same pattern was found for ratings for goal importance, likelihood of attainment and present attainment of goals. So, there were four groups of students: students with mainly intrinsic goals, students with mainly extrinsic goals, students with both intrinsic and extrinsic goals and students with no important life goals.

Both clusters with high intrinsic goals contained more female students for goal importance, for present goal attainment and for future goal attainment while male students were distributed roughly equally across all clusters. Prior studies also suggest that female college students express a greater intrinsic orientation than do their male counterparts (Kasser and Ryan, 1996; Rijavec et al., 2006).

Analyses of variance were conducted in order to determine whether any differences existed between the four groups. 
DRUŠ. ISTRAŽ. ZAGREB GOD. 20 (2011),

BR. 3 (113)

STR. $693-710$

RIJAVEC, M., BRDAR, I. MILJKOVIĆ, D. ASPIRATIONS AND...
Significant results were obtained for ratings of all psychological needs and indicators of well-being. Generally, students who strived for intrinsic and both intrinsic and extrinsic goals showed greater satisfaction of basic psychological needs followed by students with mainly extrinsic goals and those with no important life goals. A similar pattern of results was found for indicators of well-being.

On all fifteen measures of psychological needs and well-being, students with no important life goals had the lowest scores on all of them. For ten measures they significantly differ from all other groups. Since life goals are important to individuals' functioning, it is not surprising that students with no important life goals and their present attainment or hope for attainment expressed the lowest level of need satisfaction and well-being. It has been shown that people who have goals that they value are generally happier than those without valued goals (Emmons, 1996) and optimism about attaining goals is generally beneficial for well-being (Carver et al., 1996). Progression towards goals or achieving them also contributes to happiness (Brunstein, 1993; Emmons, 1991).

The second lowest scores on measures of psychological needs and well-being were obtained by students with mainly extrinsic goals. It seems that having, achieving or hoping to achieve extrinsic goals is somewhat more beneficial than having no goals at all. Out of fifteen measures these students have higher scores than those with no important life aspirations. It may be due to the fact that making progress and attaining goals may be inherently satisfying (Omodei and Wearing, 1990), as it provides individuals with feelings of competence and efficacy (Bandura, 1989; Deci and Ryan, 1985). However, relative lower ratings of basic psychological needs satisfaction and well-being comparing with other two groups are in line with previous research suggesting that placing heavy and exclusive importance on extrinsic goals is not beneficial for our well-being.

The significantly highest scores on nine measures of psychological needs and well-being were obtained by students with both extrinsic and intrinsic goals, followed by students with mainly intrinsic aspiration.

Previous research found that strongly intrinsic individuals were higher on a variety of well-being and adjustment outcomes. On the other hand, extrinsically oriented persons were lower in many indices of adjustment and well-being (Kasser and Ryan, 1993, 1996). It has been suggested that intrinsic goals promote well-being because they help satisfy basic psychological needs (Sheldon, 2002). People who strive for intrin- 
DRUŠ. ISTRAŽ. ZAGREB GOD. 20 (2011), BR. $3(113)$

STR. $693-710$

RIJAVEC, M., BRDAR, I., MILJKOVIĆ, D.: ASPIRATIONS AND... sic goals are assumed to be "in touch" with their deeper nature, and to have a greater chance of finding happiness and well-being (Ryan et al., 1996). In contrast, people focusing strongly on extrinsic goals make themselves dependent on the circumstances of the time and society in which they were born and may even become prisoners of such things as fashion, status symbols, leisure activities and so forth. Sheldon et al. (2010) documented that some people overestimate the emotional benefits of achieving extrinsic goals compared to their potential detriment. It seems that these people hold apparently misguided lay theories of happiness. As a consequence, they may ignore their basic psychological needs, so that pursuing their goals may not necessarily enhance their well-being. For instance, research has shown that people with strong extrinsic aspirations have more difficulty fulfilling their needs for competence, relatedness, and autonomy (Kasser, 2002a,b; Kasser et al., 2004; Brdar, 2006; Niemec et al., 2009).

Our results partially confirm these assumptions. Although it is evident that dominantly intrinsic goals are related to better satisfaction of basic psychological needs and better well-being, it seems that for our subject 'the best' combination is one with high scores on both intrinsic and extrinsic goals. Why is it so?

One of the possible explanations lies in the fact that Croatia is not a rich country and students have relatively few financial assets. For some of them extrinsic goals could represent means for achieving other, more important intrinsic goals (like completing their education or helping parents). In a study of goal structure in various cultures (Grouzet et al., 2005) it was found that financial success was further from hedonism and closer to safety/ physical health goals in the poorer cultures than in the wealthier cultures. This makes good sense, given that financial success in poorer cultures is probably more likely to concern basic survival than in wealthier cultures, where financial success is more often a means to acquire status and non-essential pleasantries (Wong and Ahuvia, 1998). Similarly, the finding that financial success aspirations were somewhat closer to affiliation in poorer than in wealthier nations might reflect that individuals in poorer nations may strive to make money in order to ensure the basic welfare of those they care about (for a review, see Brdar et al., 2009).

As Self-Determination Theory maintains, negative well-being consequences are likely when extrinsic goals become particularly strong, such that they are out of balance with intrinsic goals (Sheldon et al., 2004). In poorer cultures this ba- 
lance between extrinsic and intrinsic goals might be even of greater importance for subjective well-being than high intrinsic goals.

\section{CONCLUSIONS, LIMITATIONS AND FUTURE RESEARCH}

In this study, intrinsic goals were rated generally as more important than extrinsic, thus replicating in a different culture the results found in USA (Kasser and Ryan, 1996), Russia (Ryan et al., 1999), and Germany (Schmuck, 2001). The lowest satisfaction of basic psychological needs and well-being was reported by students with low scores on both intrinsic and extrinsic goals. Students who placed great value on both extrinsic and intrinsic goals had the highest scores on measures of well-being and satisfaction of basic psychological needs. Thus the claim that an emphasis on extrinsic goals yields negative well-being was partially supported. It seems that for some people in specific circumstances both intrinsic and extrinsic goals can contribute to well-being.

However, the study has several limitations. It must be stressed that participants in this study were university students and that our findings may be limited to that population in Croatia or similar transitional countries. As we have already mentioned, most of the students are in a rather bad financial situation and for some of them extrinsic goals could represent means for achieving other, more important intrinsic goals. Future research will need to investigate samples of different financial status within the population of university students as well as other populations in order to verify this assumption.

Also, it should be noted that some degree of item overlap existed between the well-being measures and basic psychological needs. For example, the intrinsic goal of meaningful relationship is very similar to the need for relatedness. This can partially explain a positive relationship between intrinsic goals and satisfaction of psychological needs.

The sample was composed of students from different faculties. Previous research has shown that students from different faculties have different life aspirations (Brdar et al., 2005). This may be due to the chosen profession as well as different social norms regarding life goals within institutions. For example, the Faculty of Teacher Education stresses mainly intrinsic aspirations while the School for Economy of Entrepreneurship stresses both kinds of life goals. This might have contributed to the grouping pattern of our participants. The same pattern might not emerge within a different sample composition. 


\section{APPENDIX 1}

\section{Satisfaction of Basic Psychological Needs and Well-Being}

Measures for Different Goal Clusters

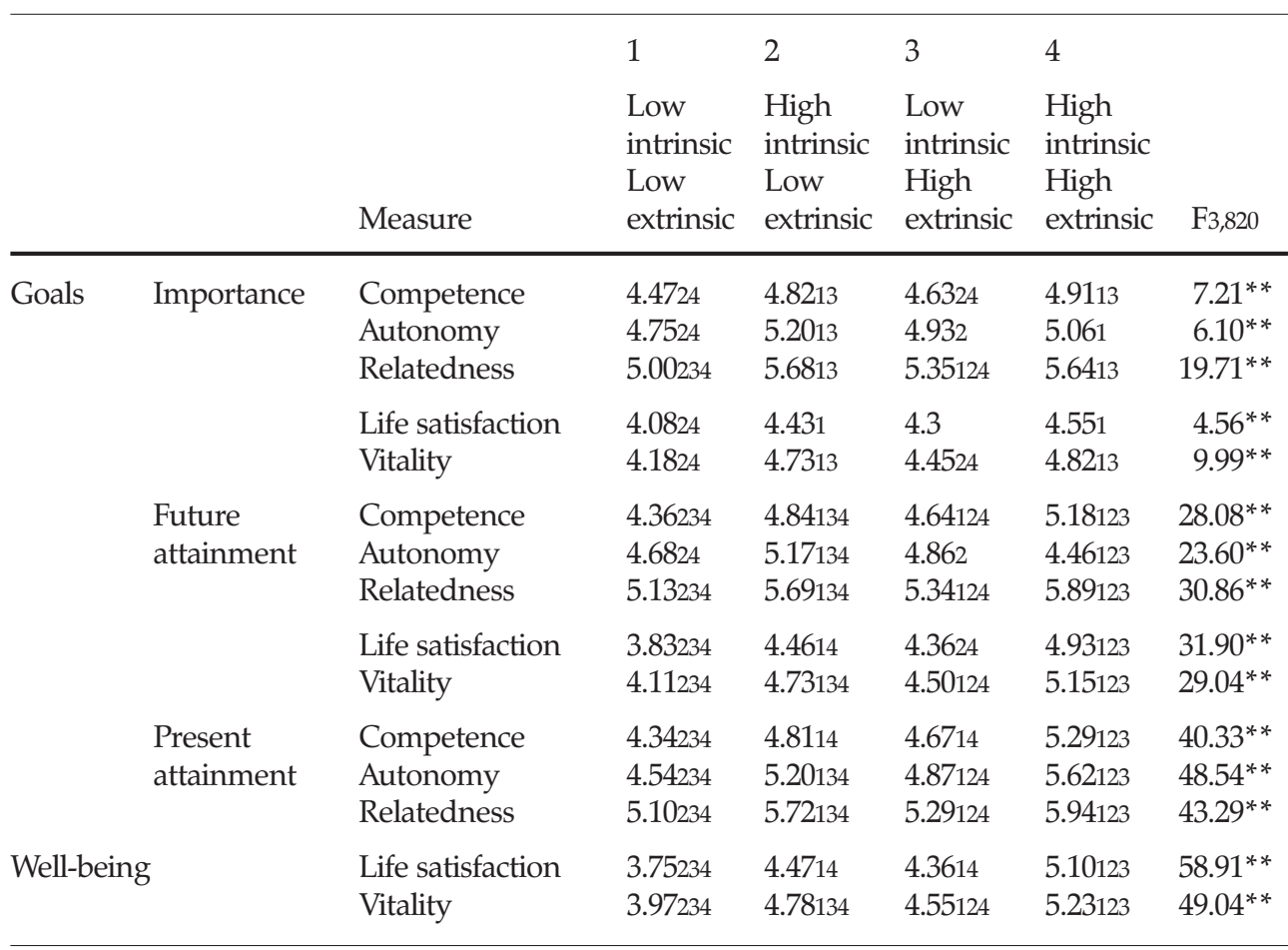

${ }^{*} \mathrm{p}<0.05,{ }^{* *} \mathrm{p}<0.01$; The numbers in the subscript denote significant differences between groups (Student Newman Keuls's test)

\section{REFERENCES}

Bandura, A. (1989), Self-Regulation of Motivation and Action Through Internal Standards and Goal-Systems. In: L. Pervin (Ed.), Goal Concepts in Personality and Social Psychology (pp. 19-85), Hillsdale, Erlbaum. Baumeister, R. (1991), Meanings of Life, New York, Guilford Press.

Baumeister, R. F. \& Leary, M. R. (1995), The Need to Belong: Desire for Interpersonal Attachments as a Fundamental Human Motivation. Psychological Bulletin, 117 (3): 497-529. doi:10.1037//0033-2909.117.3.497

Brdar, I. (2006), Life Goals and Well-Being: Are Aspirations Important for Happiness? Društvena istraživanja, 15 (4-5): 671-691.

Brdar, I., Rijavec, M. \& Miljković, D. (2005), Tko su sretni studenti? (Who are Happy Students?) Paper presented at the 13th Annual Conference of Croatian Psychologists, Osijek.

Brdar, I., Rijavec, M. \& Miljković, D. (2009), Life Goals and Well-Being: Are Extrinsic Aspirations Always Detrimental to Well-Being? Psihologijske teme/ Psychological Topics, 18 (2): 303-316. 
DRUŠ. ISTRAŽ. ZAGREB GOD. 20 (2011), BR. 3 (113)

STR. $693-710$

RIJAVEC, M., BRDAR, I. MILJKOVIĆ, D. ASPIRATIONS AND...
Brunstein, J. (1993), Personal Goals and Subjective Well-Being: A Longitudinal Study. Journal of Personality and Social Psychology, 65 (5): 1061-1070. doi:10.1037/0022-3514.65.5.1061

Carver, C. S., Lawrence, J. W. \& Scheier, M. F. (1996), A Control-Process Perspective on the Origins of Affect. In: L. L. Martin \& A. Tesser (Eds.), Striving and Feeling: Interactions between Goals and Affect (pp. 11-52), Hillsdale, Erlbaum.

Deci, E. L. \& Ryan, R. M. (1985), Intrinsic Motivation and Self-Determination in Human Behavior, New York, Plenum.

Deci, E. L. \& Ryan, R. M. (1991), A Motivational Approach to Self: Integration in Personality. In: R. Dienstbier (Ed.), Nebraska Symposium on Motivation: Perspectives on Motivation, 38 (pp. 237-288), Lincoln, University of Nebraska Press.

Deci, E. L. \& Ryan, R. M. (1993), Die Selbstbestimmungstheorie der Motivation und ihre Bedeutung für die Pädagogik (The Relevance of Self-Determination Theory of Motivation for Education). Zeitschrift für Pädagogik, 39 (2): 223-238.

Deci, E. L. \& Ryan, R. M. (2000), The "What" and "Why" of Goal Pursuits: Human Needs and the Self-Determination of Behavior. Psychological Inquiry, 11 (4): 227-268.

Diener, E., Emmons, R. A., Larsen, R. J. \& Griffin, S. (1985), The Satisfaction with Life Scale. Journal of Personality Assessment, 49 (1): 71-75.

Emmons, R. A. (1991), Personal Strivings, Daily Life Events, and Psychological and Physical Well-Being. Journal of Personality, 59 (3): 453-472. doi:10.1111/j.1467-6494.1991.tb00256.x

Emmons, R. A. (1996), Striving and Feeling: Personal Goals and Subjective Well-Being. In: J. Bargh \& P. Gollwitzer (Eds.), The Psychology of Action: Linking Motivation and Cognition to Behavior (pp. 314-337), New York, Guilford.

Gagnè, M. (2003), The Role of Autonomy Support and Autonomy Orientation in Prosocial Behavior Engagement. Motivation and Emotion, 27 (3): 199-223.

Grouzet, F., Kasser, T., Ahuvia, A., Dols, J., Kim, Y., Lau, S., Ryan, R., Saunders, S., Schmuck, P. \& Sheldon, K. M. (2005), The Structure of Goal Contents Across 15 Cultures. Journal of Personality and Social Psychology, 89 (5): 800-816. doi:10.1037/0022-3514.89.5.800

Kasser, T. (2002a), The High Price of Materialism, Cambridge, The MIT Press.

Kasser, T. (2002b), Sketches for a Self-Determination Theory of Values. In: E. L. Deci \& R. M. Ryan (Eds.), Handbook of Self-Determination Research (pp. 123-140), Rochester, University of Rochester Press.

Kasser, T. \& Ahuvia, A. (2002), Materialistic Values and Well-Being in Business Students. European Journal of Social Psychology, 32 (1): 137-146. doi:10.1002/ejsp.85

Kasser, T. \& Ryan, R. M. (1993), A Dark Side of the American Dream: Correlates of Financial Success as a Central Life Aspiration. Journal of Personality and Social Psychology, 65 (2): 410-422. doi:10.1037/0022-3514. 65.2.410 
DRUŠ. ISTRAŽ. ZAGREB GOD. 20 (2011), BR. $3(113)$

STR. $693-710$

RIJAVEC, M., BRDAR, I., MILJKOVIĆ, D. ASPIRATIONS AND..
Kasser, T. \& Ryan, R. M. (1996), Further Examining the American Dream: Differential Correlates of Intrinsic and Extrinsic Goals. Personality and Social Psychology Bulletin, 22 (3): 280-287. doi:10.1177/ 0146167296223006

Kasser, T. \& Ryan, R. M. (2001), Be Careful What You Wish For: Optimal Functioning and the Relative Attainment of Intrinsic and Extrinsic Goals. In: P. Schmuck \& K. Sheldon (Eds.), Life Goals and Well-Being (pp. 116-131), Göttingen, Hogrefe.

Kasser, T., Ryan, R. M., Couchman, C. E. \& Sheldon, K. M. (2004), Materialistic Values: Their Causes and Consequences. In: T. Kasser, \& A. D. Kanner (Eds.), Psychology and Consumer Culture: The Struggle for a Good Life in a Materialistic World (pp. 11-28), Washington, American Psychological Association.

Niemiec, C. P., Ryan, R. M. \& Deci, E. L. (2009), The Path Taken: Consequences of Attaining Intrinsic and Extrinsic Aspirations in Post-College Life. Journal of Research in Personality, 43 (3): 291-306. doi:10. 1016/j.jrp.2008.09.001

Omodei, M. M. \& Wearing, A. J. (1990), Need Satisfaction and Involvement in Personal Projects: Toward an Integrative Model of Subjective Well-Being. Journal of Personality and Social Psychology, 59 (4): 762-769. doi:10.1037/0022-3514.59.4.762

Peterson, C., Park, N. \& Seligman, M. E. P. (2005), Orientations to Happiness and Life Satisfaction: The Full Life versus the Empty Life. Journal of Happiness Studies, 6 (1): 25-41. doi:10.1007/s10902-004-1278-z

Richins, M. L. (1994), Special Possessions and the Experience of Material Values. Journal of Consumer Research, 21 (3): 504-521. doi:10. 1086/209415

Rijavec, M., Brdar, I. \& Miljkovic, D. (2006), Extrinsic vs. Intrinsic Life Goals, Psychological Needs and Life Satisfaction. In: A. Delle Fave (Ed.), Dimensions of Well-Being. Research and Intervention (pp. 91-104), Milano, Franco Angeli.

Ryan, R. M. (1995), Psychological Needs and the Facilitation of Integrative Processes. Journal of Personality, 63 (3): 397-427. doi:10. 1111/j.1467-6494.1995.tb00501.x

Ryan, R. M., Chirkov, V. I., Little, T. D., Sheldon, K. M., Timoshin, E. \& Deci, E. L. (1999), The American Dream in Russia: Extrinsic Aspirations and Well-Being in Two Cultures. Personality and Social Psychology Bulletin, 25 (12): 1509-1524. doi:10.1177/01461672992510007

Ryan, R. M., Sheldon, K. M., Kasser, T. \& Deci, E. L. (1996), All Goals are Not Created Equal: An Orgasmic Perspective on the Nature of Goals and Their Regulation. In: P. M. Gollwitzer \& J. A. Bargh (Eds.), The Psychology of Action: Linking Cognition and Motivation to Behavior (pp. 7-26), New York, Guilford.

Ryan, R. M. \& Deci, E. L. (2000), Self-Determination Theory and the Facilitation of Intrinsic Motivation, Social Development, and Well-Being. American Psychologist, 55 (1): 68-78. doi:10.1037//0003-066X. 55.1.68

Ryan, R. M. \& Deci, E. L. (2002), Overview of Self-Determination Theory: An Organismic-Dialectical Perspective. In: E. L. Deci \& R. M. 
DRUŠ. ISTRAŽ. ZAGREB GOD. 20 (2011), BR. 3 (113)

STR. $693-710$

RIJAVEC, M., BRDAR, I. MILJKOVIĆ, D. ASPIRATIONS AND..
Ryan (Eds.), Handbook of Self-Determination Research (pp. 65-86), Rochester, University of Rochester Press.

Ryan, R. M. \& Frederick, C. (1997), On Energy, Personality, and Health: Subjective Vitality as a Dynamic Reflection of Well-Being. Journal of Personality, 65 (3): 529-565. doi:10.1111/j.1467-6494.1997.tb 00326.x

Saunders, S. (2001), Fromm's Marketing Character and Rokeach Values. Social Behavior and Personality, 29 (2): 191-195. doi:10.2224/sbp. 2001.29.2.191

Saunders, S. \& Munro, D. (2000), The Construction and Validation of a Consumer Orientation Questionnaire (SCOI) Designed to Measure Fromm's (1955) 'Marketing Character' in Australia. Social Behavior and Personality, 28 (3): 219-240. doi:10.2224/sbp.2000.28.3.219

Schmuck, P. (2001), Intrinsic and Extrinsic Life Goals Preferences as Measured Via Inventories and Via Priming Methodologies: Mean Differences and Relations with Well-Being. In: P. Schmuck \& K. M. Sheldon (Eds.), Life Goals and Well-Being: Towards a Positive Psychology of Human Striving (pp. 132-147), Seattle, Hogrefe and Huber Publishers.

Schmuck, P., Kasser, T. \& Ryan, R. M. (2000), Intrinsic and Extrinsic Goals: Their Structure and Relationship to Well-Being in German and U.S. College Students. Social Indicators Research, 50 (2): 225-241.

Schwartz, B. (1994), The Cost of Living: How Market Freedom Erodes the Best Things in Life, New York, Norton.

Sheldon, K. M. (2002), The Self-Concordance Model of Healthy Goal-Striving: When Personal Goals Correctly Represent the Person. In: E. L. Deci \& R. M. Ryan (Eds.), Handbook of Self-Determination Research (pp. 65-86), Rochester, University of Rochester Press.

Sheldon, K. M. \& Elliot, A. J. (1999), Goal Striving, Need Satisfaction, and Longitudinal Well-Being: The Self-Concordance Model. Journal of Personality and Social Psychology, 76 (3): 482-497. doi:10.1037//00223514.76.3.482

Sheldon, K. M., Elliot, A. J., Ryan, R. M., Chirkov, V., Kim, Y., Wu, C., Demir, M. \& Sun, Z. (2004), Self-Concordance and Subjective Well-Being in Four Cultures. Journal of Cross-Cultural Psychology, 35 (2): 209-223. doi:10.1177/0022022103262245

Sheldon, K. M., Gunz, A., Nichols, C. P. \& Ferguson, Y. (2010), Extrinsic Value Orientation and Affective Forecasting: Overestimating the Rewards, Underestimating the Costs. Journal of Personality, 78 (1): 149-178. doi:10.1111/j.1467-6494.2009.00612.x

Sheldon, K. M. \& Kasser, T. (1998), Pursuing Personal Goals: Skills Enable Progress, but Not All Progress is Beneficial. Personality and Social Psychology Bulletin, 24 (12): 1319-1331. doi:10.1177/01461672982412006 White, R. W. (1959), Motivation Reconsidered: The Concept of Competence. Psychological Review, 66 (5): 297-333.

Wong, N. \& Ahuvia, A. C. (1998), Personal Taste and Family Face: Luxury Consumption in Confucian and Western Societies. Psychology and Marketing, 15 (5): 423-441. doi:10.1002/(SICI)1520-6793(199808)15:5 $<423:: A I D-M A R 2>3.0 . C O ; 2-9$ 
DRUŠ. ISTRAŽ. ZAGREB GOD. 20 (2011), BR. $3(113)$

STR. $693-710$

RIJAVEC, M., BRDAR, I. MILJKOVIĆ, D.: ASPIRATIONS ANDD.

\section{Životne aspiracije i dobrobit: odnos ekstrinzičnih $\mathrm{i}$ intrinzičnih ciljeva}

Majda RIJAVEC

Učiteljski fakultet, Zagreb

Ingrid BRDAR

Filozofski fakultet, Rijeka

Dubravka MILJKOVIĆ

Učiteljski fakultet, Zagreb

Cili ovoga rada bio je istražiti mogu li se sudionici razvrstati u grupe s obzirom na svoje intrinzične i ekstrinzične životne ciljeve te kako se te grupe razlikuju po zadovoljenju temelinih psiholoških potreba i dobrobiti. $\mathrm{Na} 835$ studenata primijenjena su četiri upitnika: Indeks aspiracija (Aspiration Index, Kasser i Ryan, 1996.), Skala temeljnih psiholoških potreba (The Basic Psychological Needs Scale, Gagnè, 2003.), Skala subjektivne vitalnosti (Subjective Vitality Scale, Ryan i Frederick, 1997.) i Skala zadovoljstva životom (The Satisfaction with Life Scale, Diener i sur., 1985.). K-Means klasterskom analizom sudionici su razvrstani prema svojim životnim aspiracijama - s obzirom na njihovu važnost, sadašnju ostvarenost i izglednost ostvarivanja u budućnosti. Za sva ova tri kriterija dobivena su četiri klastera. Prvi uključuje pojedince s visokim ekstrinzičnim i niskim intrinzičnim životnim ciljevima. U drugom su oni s visokim intrinzičnim i niskim ekstrinzičnim aspiracijama. Treći uključuje one s visokim i intrinzičnim i ekstrinzičnim ciljevima, a četvrti one s niskima - intrinzičnima i ekstrinzičnima. Grupa s visokim rezultatom i na intrinzičnim i na ekstrinzičnim ciljevima ima i najviše rezultate na mjerama dobrobiti. Slijedi grupa s visokim intrinzičnim i niskim ekstrinzičnim ciljevima. Te dvije grupe, u usporedbi s onima koje imaju niske intrinzične ciljeve, imaju i više rezultate na svim temeljnim psihološkim potrebama. Ovi nalazi sugeriraju da dobrobiti mogu pridonositi i intrinzični i ekstrinzični ciljevi.

Ključne riječi: životni ciljevi, intrinzični ciljevi, ekstrinzični ciljevi, psihološke potrebe, dobrobit 
DRUŠ. ISTRAŽ. ZAGREB GOD. 20 (2011) BR. 3 (113)

STR. $693-710$

RIJAVEC, M., BRDAR, I., MILJKOVIĆ, D.: ASPIRATIONS ANDD.

\section{Lebensziele und Wohlergehen: Extrinsische und intrinsische Zielsetzungen im gegenseitigen Bezug}

Majda RIJAVEC

Lehrerakademie, Zagreb

Ingrid BRDAR

Philosophische Fakultät, Rijeka

Dubravka MILJKOVIĆ

Lehrerakademie, Zagreb

Mit dieser Arbeit sollte untersucht werden, ob die Menschen hinsichtlich ihrer intrinsischen und extrinsischen Lebensziele in unterschiedliche Gruppen unterteilt werden können und ob sich diese Gruppen in Bezug auf die Befriedigung ihrer psychologischen Grundbedürfnisse unterscheiden. An der Untersuchung nahmen 835 Studenten teil, die insgesamt vier Umfragebögen beantworteten. Das waren: ein

Aspirationsindex (Aspiration Index, Kasser und Ryan, 1996), ein Fragebogen zur Ermittlung psychologischer Grundbedürfnisse (The Basic Psychological Needs Scale, Gagné, 2003), ein Fragebogen zur Ermittlung der subjektiven Vitalität (Subjective Vitality Scale, Ryan und Frederick, 1997) und ein Fragebogen zur Ermittlung der Lebenszufriedenheit (The Satisfaction with Life Scale, Diener et al., 1985). Mittels einer k-Means-Cluster-Analyse wurden die Umfrageteilnehmer im Hinblick auf ihre jeweiligen Lebensziele in Gruppen unterteilt, und zwar hinsichtlich der Bedeutung der jeweiligen Ziele, deren bislang erfolgter Verwirklichung sowie der Aussicht auf deren zukünftige Realisierung. Die genannten drei Kriterien ergaben vier verschiedene Cluster. Diese enthalten jeweils: Personen mit hochgesteckten extrinischen und einfach gehaltenen intrinsischen Lebenszielen; Personen mit hochgesteckten intrinsischen und einfach gehaltenen extrinsischen Lebenszielen; Personen mit hochgesteckten intrinsischen und extrinsischen Lebenszielen; Personen mit niedrigen intrinsischen und extrinsischen Lebenszielen. Die Probandengruppe mit sowohl ehrgeizigen intrinsischen als auch ehrgeizigen extrinsischen Lebenszielen konnte die höchsten Werte in puncto persönliches Wohlergehen verbuchen. Es folgt die Gruppe mit ehrgeizigen intrinsischen und anspruchslosen extrinsischen Zielen. Diese beiden Gruppen zeigten, im Vergleich zu jenen mit niedrigen intrinsischen Zielsetzungen, höhere Werte bezüglich sämtlicher psychologischer Grundbedürfnisse. Diese Daten suggerieren, dass sowohl intrinsische als auch extrinsische Ziele zum persönlichen Wohlergehen beitragen können.

Schlüsselbegriffe: Lebensziele, intrinsische und extrinsische Zielsetzungen, psychologische Bedürfnisse, Wohlergehen 